\title{
ANALISIS TINGKAT KENIKMATAN BERAKTIFITAS FISIK PESERTA DIDIK PENDIDIKAN JASMANI SEKOLAH MENENGAH KEJURUAN
}

\author{
Hendra Mashuri \\ Pascasarjana Keguruan Olahraga \\ Universitas Nusantara PGRI Kediri \\ email: hendramashuri@unpkediri.ac.id
}

\begin{abstract}
ABSTRAK
Pendidikan jasmani mempunyai peran yang strategis dalam upaya pembentukan manusia yang sehat jasmani, rohani, dan sosial. Melalui aktifitas fisik dalam pendidikan jasmani yang menyenangkan, peserta didik diharapkan mampu membentuk gaya hidup yang sehat. Aktifitas fisik yang baik adalah aktifitas fisik yang bisa memberikan kenikmatan bagi peserta didik. Penelitian ini untuk mengetahui tingkat kenikmatan aktifitas fisik peserta didik pendidikan jasmani sekolah menengah kejuruan. Pendekatan penelitian ini adalah kuantitatid dengan jenis penelitian deskriptif. Hasil penelitian menunjukkan bahwa peserta didik sekolah menengah kejuruan menikmati aktifitas fisik yang dilakukan selama kegiatan belajar mengajar pendidikan jasmani. Peserta didik merasa aktifitas fisik dalam pendidikan jasmani sangat nyaman dan tidak membuat frustasi serta peserta didik merasa dampak aktifitas fisik membuat dirinya lebih segar.
\end{abstract}

Kata Kunci: kenikmatan aktifitas fisik, pendidikan jasmani, sekolah menengah kejuruan

\begin{abstract}
Physical education has a strategic role in efforts to form healthy people physically, spiritually, and sosially. Through physical activities in fun physical education, students are expected to be able to form a healthy lifestyle. Good physical activity is physical activity that can provide enjoyment for students. This study was to determine the level of physical activity enjoyment of vocational high school physical education students. This research approach is quantitative with descriptive research type. The results showed that vocational high school students enjoyed physical activities undertaken during physical education teaching and learning activities. Students feel physical activity in physical education is very comfortable and not frustrating and students feel the impact of physical activity makes themselves more refreshed.
\end{abstract}

Keywords: enjoyment of physical activity, physical education, vocational high school

\footnotetext{
${ }^{\square}$ Alamat korespondensi:

E-mail: hendramashuri@unpkediri.ac.id Info Artikel

Dikirim : 20 Oktober 2019

Diterima : 24 Oktober 2019

DOI $\quad$ : https://doi.org/10.33503/jp.jok.v3i1.602
} 


\section{PENDAHULUAN}

Siedentop (1991 dalam Abduljabar, 2011), seorang pakar pendidikan jasmani mengatakan bahwa pendidikan jasmani dewasa ini dapat diterima secara luas sebagai model "pendidikan melalui aktifitas jasmani” yang berkembang sebagai akibat dari merebaknya telaan pendidikan gerak pada akhir abad ke-20 dan menekankan pada kebugaran jasmani, penguasaan keterampilan, pengetahuan, dan perkembangan sosial. Oleh sebab itu pendidikan jasmani merupakan bagian dari pendidikan formal yang berlangsung di sekolah-sekolah dari pendidikan dasar sampai dengan menengah (Utama, 2011).

Pendidikan jasmani merupakan pendidikan yang melibatkan aktifitas fisik guna memperoleh kemampuan dan keterampilan jasmani (Hanief, Subekti, \& Mashuri, 2018). Upaya untuk mendapatkan kemampuan dan keterampilan jasmani peserta didik tidak lepas dari keaktifan peserta didik dalam mengikuti kegiatan dalam pendidikan jasmani (Mashuri, 2017). Keaktifan peserta didik untuk melakukan kegiatan pendidikan jasmani harus didasari oleh kesenangan peserta didik akan kegiatan pendidikan jasmani. Hasil penelitian sebelumnya menyatakan bahwa pseserta didik akan lebih cenderung melakukan aktifitas fisik jika mereka menganggap kegiatan tersebut menyenangkan (Carroll \& Loumidis, 2001). Penelitian yang dilakukan Carrol dan Loumidis menunjukkan bahwa peserta didik lebih menikmati aktifitas fisik di luar sekolah/kelas, namun tidak menunjukkan perbedaan yang signifikan antara paserta didik laki-laki dan perempuan dalam kenikmatan beraktifitas fisik.

Weiss menyatakan bahwa anak-anak (peserta didik) akan lebih cenderung untuk berpartisipasi dalam aktifitas fisik jika mereka menganggap kegiatan itu menyenangkan dan kemungkinan partisipasi terus akan meningkat karena motovasi insrinsik (Showab \& Djawa, 2019). Jika aktifitas fisik yang dilakukan peserta didik menyenangkan dan memberi kenikmatan, maka peserta didik akan berusaha untuk melakukan aktifitas fisik terus menerus dan kemungkinan besar akan meningkatkan motivasi diri untuk terus berpartisipasi terhadap aktifitas fisik yang dilakukannya.

Motivasi adalah wujud yang tidak Nampak pada orang dan yang tidak bisa kita amati secara langsung (Gunawan, 2019). Namun motivasi peserta didik bisa 
diamati melalui tingkah laku yang merupakan dampak dari dorongan diri untuk bersikap. Dorongan tersebut akn timbul dari diri karena adanya kenikmatan sebagai hasil beraktifitas. Motivasi diri akan memberikan dorongan yang besar kepada peserta didik untuk lebih aktif dalam kegiatan aktifitas fisik.

Penelitian dilakukan oleh Kremer dkk menunjukkan bahwa 69\% dari sampel dikatakan bahwa kegembiraan/kenikmatan merupakan faktor yang membuat anak-anak lebih tertarik dengan olahraga yang mereka pilih dan 75 persen menyatakan kurangnya kegembiraan/kenikmatan adalah factor yang membuat peserta didik kurang tertarik dengan olahraga (Showab \& Djawa, 2019). Penelitian tersebut dengan tegas menunjukkan lebih dari setengah jumlah sampel tertarik untuk melakukan aktifitas fisik jika aktifitas fisik tersebut memberikan kenikmatan. Oleh sebab itu guru pendidikan jasmani harus bisa mengemas materi pendidikan jasmani dengan permainan yang memberikan kegembiraan dan kepuasan kepada siswa.

Guru pendidikan jasmani adalah guru yang selalu dinanti kehadirannya oleh siswa. Guru pendidikan jasmani dianggap guru yang paling menyenangkan karena identik dengan mata pelajaran bermain (Wibowo, 2018). Guru pendidikan jasmani secara nyata merupakan idola bagi siswa karena memberikan kesenangan dan kenikmatan kepada peserta didik melalui aktifitas fisik karena ruang lingkup pendidikan jasmani terdiri dari play, game, dan sport (Winarno, 2006). Lebih lanjut Winarno menjelaskan bahwa play adalah suatu aktifitas bermain yang mempunyai ciri bebas, tidak tentu, terpisah, tidak produktif, dan ditentukan peraturan yang sifatnya tidak berat. Sedangkan game adalah suatu aktifitas yang mempunyai adanya kompetensi dan hasil yang ditentukan oleh keterampilan fisik, strategi, atau kesempatan. Sport adalah suatu aktifitas permainan yang dilembagakan, terstruktur, dan mempertunjukkan keterampilan.

Berdasarkan ruang lingkup pendidikan jasmani, tentu aktifitas yang bersifat play, game, dan sport akan memberikan kegembiraan dan kenikmatan kepada pserta didik. Mengingat bahwa play merupakan aktifitas yang sedikit syarat aturan sehingga peserta didik akan bebas bergerak dan meluapkan emosi dalam aktifitas fisik. Peserta didik juga akan merasakan game yang notabenya 
adalah aktifitas yang memberikan rasa fun bagi pelaku permainan. Sedangkan sport merupakan upaya agar peserta didik bisa bergerak sesuai aturan gerakan dalam cabang olahraga, sehingga gerakan yang ditampilkan peserta didik bersifat efektif dan efisien serta aman.

Pendidikan jasmani di sekolah memberikan kesempatan kepada peserta didik untuk mengembangkan potensi diri secara jasmani, rohani, dan sosial yang dibalut dengan perasaan menyenangkan dan mendapatkan kenikmatan dari aktifitas fisik yang dilakukan peserta didik. Pengertian tersebut berlaku kepada semua tingkatan pendidikan sekolah, mulai dari sekolah dasar (SD), sekolah menengah pertama (SMP sederajat) dan sekolah menengah atas (SMA sederajat). Pada tingkat sekolah menengah atas (SMA sederajat), ada keunikan tersendiri dimana pada derajat pendidikan ini ada kelompok belajar yang disesuaikan dengan bakat minat serta kesempatan untuk bekerja, yaitu sekolah menengah kejuruan (SMK).

Sekolah menengah kejuruan merupakan salah satu lembaga pendidikan yang bertanggung jawab menciptakan sumber daya manusia yang memiliki kemampuan keterampilan dan keahlian dalam dunia kerja (Firdausi \& Barnawi, 2012). Peraturan Pemerintah Republik Indonesia Nomor 29 Tahun 1990 tentang Pendidikan Menengah mempertegas definisi sekolah menengah kejuruan adalah pendidikan pada jenjang pendidikan menengah yang mengutamakan pengembangan kemampuan siswa untuk melaksanakan jenis pekerjaan tertentu. Peserta didik sekolah menengah kejuruan disiapkan untuk memasuki lapangan kerja serta mengembangkan sikap professional (Presiden Republik Indonesia, 1990)

Selama proses pendidikan di sekolah menengah kejuruan, peserta didik akan lebih banyak praktik lapangan sesuai jurusan yang diambil. Lingkungan sekolah mendorong peserta didik untuk lebih menyukai praktik lapangan daripada teori di kelas. Hal ini membentuk karakter peserta didik untuk menyukai kegiatan praktik lapangan. Karakter tersebut searah dengan proses pembelajaran pendidikan jasmani di sekolah, sehingga dapat dikaitkan bahwa peserta didik jenjang sekolah menengah kejuruan akan menikmati aktifitas fisik dalam pendidikan jasmani. 
Kenikmatan beraktifitas fisik terdiri dari beberapa variabel. Beberapa penelitian menunjukkan bahwa kenikmatan beraktifitas fisik merupakan motivasi primer untuk menarik peserta didik beraktifitas fisik (Gill, Gross, \& Huddleston, 1983). Selain itu pertumbuhan dan perkembangan tubuh juga sebagai faktor kenikmatan beraktifitas bagi peserta didik (Brustad, 2016). Perasaan peserta didik menjadi fokus utama dalam menemukan kenikmatan beraktifitas fisik yang terdiri dari perasaan senang akan aktifitas fisik, tertarik untuk melakukan aktifitas fisik, menyukai aktifitas fisik yang dilakukan, asyik dalam proses aktifitas fisik, mendapatkan energi selama beraktifitas fisik, membuat peserta didik bahagia, merasa baik secara fisik saat melakukan aktifitas, merasa aktifitas fisik yang dilakukan membuat diri menjadi lebih kuat, memuaskan diri peserta didik, memotivasi untuk beraktifitas, memberikan rasa prestasi, menyegarkan diri, dan merasa aktifitas fisik ini adalah kegiatan yang harus dilakukan daripada kegiatan lain.

Berdasarkan karakter peserta didik yang terbentuk dari lingkungan belajar, maka timbul pertanyaan besar tentang kenikmatan beraktifitas fisik peserta didik sekolah menengah kejuruan pada mata pelajaran pendididkan jasmani. Penelitian ini untuk menemukan variabel kenikmatan fisik peserta didik yang kuat dan lemah, serta sebagai pengetahuan tentang kondisi psikologis peserta didik sekolah menengah kejuruan dalam beraktifitas fisik.

\section{METODE}

Penelitian ini merupakan penelitian yang menggunakan paradigma positivistic dengan pendekatan kuantitatif dan jenis penelitian deskriptif. Penelitian ini mengungkapkan fakta dari kondisi kenikmatan beraktifitas fisik peserta didik selama mengikuti kegiatan belajar mengajar pendidikan jasmani di sekolah.

Populasi dalam penelitian ini adalah seluruh siswa sekolah menengah kejuruan negeri se Kota Kediri. Jumlah sekolah menengah kejuruan negeri di Kota Kediri ada 3 sekolah, yaitu SMK Negeri 1 Kediri, SMK Negeri 2 Kediri, dan SMK Negeri 3 Kediri. Berdasarkan data dari Direktorat Jendral Pendidikan Dasar dan Menengah, jumlah peserta didik SMK Negeri Kediri adalah 2.063 peserta 
didik. Jumlah peserta didik di SMK Negeri 2 Kediri adalah 1.994 peserta didik. Sedangkan SMK Negeri 3 Kediri berjumlah 975 peserta didik (Direktorat Jendral Pendidikan Dasar dan Menengah, 2019). Jumlah total populasi penelitian adalah 5.032 peserta didik. Sample yang diambil secara acak adalah dengan mengambil 67 peserta didik di sekolah menengah kejuruan negeri 1 Kediri, 67 peserta didik di sekolah menengah kejuruan negeri 2 Kediri, dan 66 peserta didik di sekolah menengah kejuruan negeri 3 Kediri. Jadi total sampel adalah 200 peserta didik.

Setelah didapatkan sampel, maka setiap peserta didik akan diberi lembar kuisioner PACE (Physical Activity Enjoyment Scale) (Kendzierski \& DeCarlo, 2016). Peserta didik mengisi lembar kuisioner setelah mereka melakukan aktifitas fisik pendidikan jasmani. Variabel yang terdapat dalam kuisioner PACE terdiri dari kenikmatan beraktifitas fisik, ketertarikan beraktifitas fisik, kesukaan beraktifitas fisik, kesenangan beraktifitas fisik, keasyikan beraktifitas fisik, bersukacita saat beraktifitas fisik, mendapatkan energi selama beraktifitas fisik, bahagia selama beraktifitas fisik, gerakan yang dilakukan nyaman, mendapat kebaikan saat beraktifitas fisik, mendapatkan kekuatan saat beraktifitas fisik, tidak frustasi saat melakukan aktifitas fisik, mendapatkan kepuasan selama beraktifitas fisik, merasa gembira, termotivasi untuk beraktifitas fisik, merasa mendapat prestasi saat beraktifitas fisik, merasa segar setelah melakukan aktifitas fisik, dan merasa tidak ada kegiatan lain yang lebih baik untuk dilakukan selain beraktifitas fisik.

Peserta didik akan memberi jawaban berupa memilih skala di tiap variabel. Skala di tiap variabel antara $1-7$, yang berisi skala negatif dan positif. Skala positif berarti nilai terbesar akan mendapatkan poin yang besar. Skala negatif berarti nilai terkecil akan mendapatkan poin yang besar. Adapun kisi-kisi kuisioner PACE adalah sebagai berikut.

Tabel 1. Kisi-Kisi Instrumen Kenikmatan Beraktifitas Fisik

\begin{tabular}{|c|c|c|}
\hline Konsep & Variabel & Indikator \\
\hline $\begin{array}{l}\text { Kenikmatan } \\
\text { beraktifitas }\end{array}$ & $\begin{array}{l}\text { Kenikmatan } \\
\text { beraktifitas fisik }\end{array}$ & $\begin{array}{l}\text { Peserta didik menikmati aktifitas fisik } \\
\text { atau membenci aktifitas fisik }\end{array}$ \\
\hline fisik & Ketertarikan & Peserta didik merasa tertarik atau merasa \\
\hline
\end{tabular}




\begin{tabular}{|c|c|}
\hline beraktifitas fisik & bosan saat beraktifitas fisik \\
\hline $\begin{array}{l}\text { Kesukaan beraktifitas } \\
\text { fisik }\end{array}$ & $\begin{array}{l}\text { Peserta didik menemukan gerak yang } \\
\text { disukai atau tidak menemukan gerakan }\end{array}$ \\
\hline $\begin{array}{l}\text { Kesenangan } \\
\text { beraktifitas fisik }\end{array}$ & $\begin{array}{l}\text { Peserta didik menemukan kesenangan } \\
\text { saat beraktifitas fisik atau tidak } \\
\text { menemukan kesenangan }\end{array}$ \\
\hline $\begin{array}{l}\text { Keasyikan beraktifitas } \\
\text { fisik }\end{array}$ & $\begin{array}{l}\text { Peserta didik merasa asyik saat } \\
\text { beraktifitas fisik atau tidak sama sekali } \\
\text { merasa asyik saat beraktifitas fisik. }\end{array}$ \\
\hline $\begin{array}{ll}\text { Bersukacita saat } \\
\text { beraktifitas fisik }\end{array}$ & $\begin{array}{l}\text { Peserta didik merasa bersuka cita saat } \\
\text { beraktifitas fisik atau sama sekali tidak }\end{array}$ \\
\hline $\begin{array}{l}\text { Mendapat energi } \\
\text { beraktifitas fisik }\end{array}$ & $\begin{array}{l}\text { Peserta didik mendapatkan energi saat } \\
\text { beraktifitas fisik atau merasa kelelahan }\end{array}$ \\
\hline $\begin{array}{l}\text { Kebahagiaan } \\
\text { beraktifitas fisik }\end{array}$ & $\begin{array}{l}\text { Peserta didik merasa aktifitas fisik } \\
\text { membuat bahagia atau membuat depresi }\end{array}$ \\
\hline $\begin{array}{l}\text { Kenyamanan } \\
\text { beraktifitas fisik }\end{array}$ & $\begin{array}{l}\text { Peserta didik merasa nyaman dengan } \\
\text { tugas gerak yang dilakukan atau merasa } \\
\text { kesulitan }\end{array}$ \\
\hline Kebaikan secara fisik & $\begin{array}{l}\text { Peserta didik merasa baik secara fisik } \\
\text { saat beraktifitas fisik atau merasa tidak } \\
\text { enak secara fisik saat melakukan } \\
\text { aktifitas fisik }\end{array}$ \\
\hline $\begin{array}{l}\text { Kekuatan beraktifitas } \\
\text { fisik }\end{array}$ & $\begin{array}{l}\text { Peserta didik merasa aktifitas fisik yang } \\
\text { yang dilakukan menguatkan atau } \\
\text { melemahkan diri peserta didik }\end{array}$ \\
\hline $\begin{array}{l}\text { Tidak frustasi } \\
\text { beraktifitas fisik }\end{array}$ & $\begin{array}{l}\text { Peserta didik merasa bisa melakukan } \\
\text { gerakn dengan baik atau merasa frustasi } \\
\text { dengan tugas gerak yang dilakukan }\end{array}$ \\
\hline $\begin{array}{l}\text { Kepuasan beraktifitas } \\
\text { fisik }\end{array}$ & $\begin{array}{l}\text { Peserta didik merasa puas dengan } \\
\text { melakukan aktifitas fisik atau sama } \\
\text { sekali tidak memberikan kepuasan gerak }\end{array}$ \\
\hline
\end{tabular}




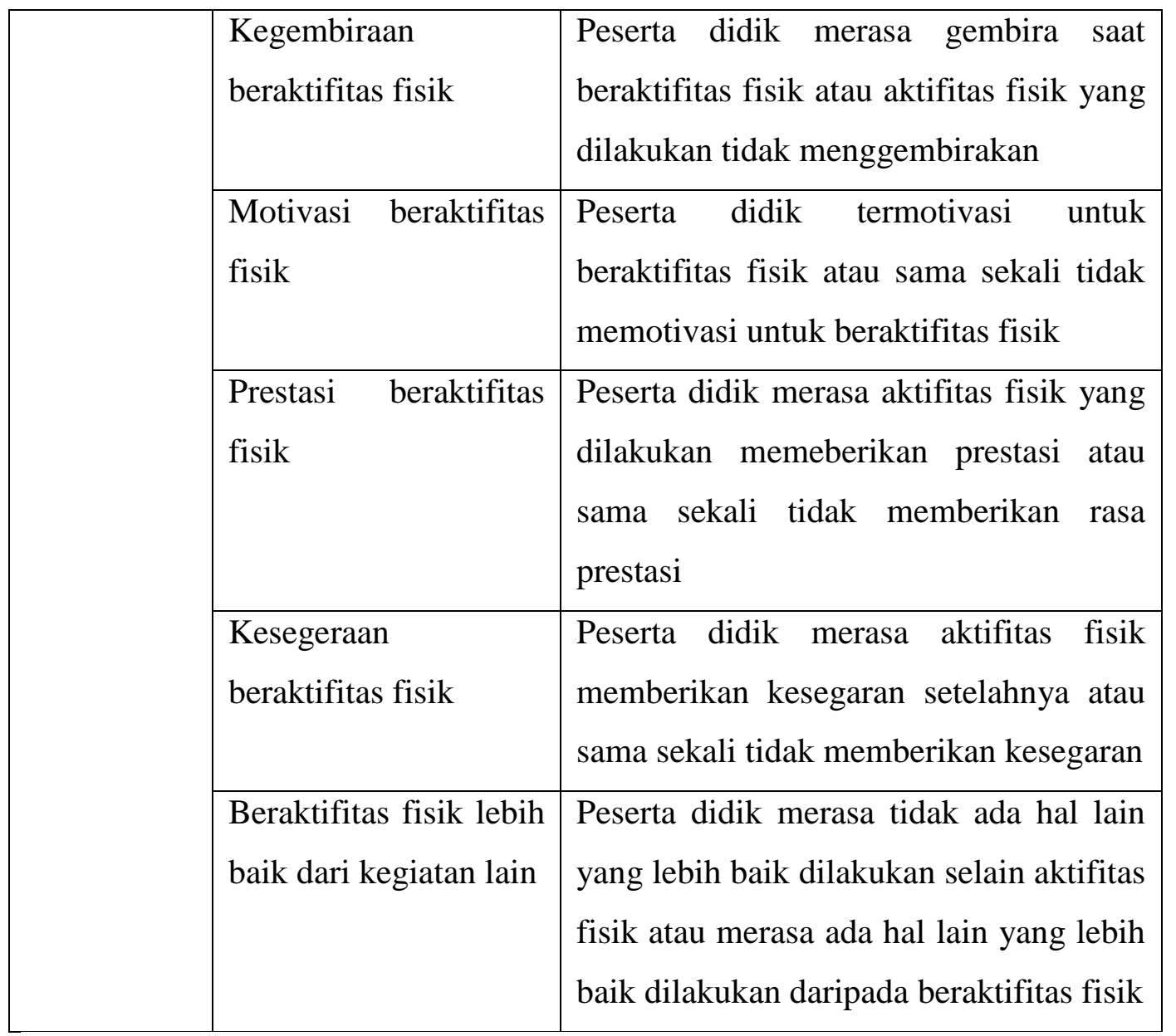

Hasil kuisioner akan dianalisis dengan rumus persentase dan dikategorikan berdasarkan tujuh skala penilaian PACE. Kategori kenikmatan beraktifitas fisik adalah sebagai berikut.

Tabel 2. Kategori Kenikmatan Beraktifitas Fisik

\begin{tabular}{|l|c|c|}
\hline \multicolumn{1}{|c|}{ Kategori } & Nilai & $\begin{array}{c}\text { Persentase } \\
(\mathbf{\%})\end{array}$ \\
\hline Sungguh sangat menikmati aktifitas fisik & 7 & $85,72-100$ \\
\hline Sangat menikmati aktifitas fisik & 6 & $71,43-85,71$ \\
\hline Menikmati aktifitas fisik & 5 & $57,15-71,42$ \\
\hline Cukup menikmati aktifitas fisik & 4 & $42,86-57,14$ \\
\hline Kurang menikmati aktifitas fisik & 3 & $28,58-42,85$ \\
\hline Tidak menikmati aktifitas fisik & 2 & $14,30-28,57$ \\
\hline Sama sekali tidak menikmati aktifitas fisik & 1 & $0-14,28$ \\
\hline
\end{tabular}

Setelah mendapatkan nilai dari penghitungan, maka akan dilanjutkan dengan analisis variabel yang kuat dan variabel yang lemah sebagai faktor penentu kenikmatan beraktifitas fisik peserta didik selama mengikuti kegiatan 
belajar mengajar pendidikan jasmani di sekolah menengah kejuruan. Variabel terkuat dan terlemah akan dianalisis dan didiskusikan dengan penelitian lebih dalam yang berupa observasi.

\section{HASIL DAN PEMBAHASAN}

Data kenikmatan beraktifitas fisik peserta didik sekolah menengah kejuruan selama mengikuti kegiatan belajar mengajar pendidikan jasmani dapat dideskripsikan sebagai berikut.

Tabel 3. Deskripsi Statistik Kenikmatan Beraktifitas Fisik

\begin{tabular}{|l|c|c|c|c|c|c|}
\hline & $\mathrm{N}$ & Minimum & Maximum & Mean & $\begin{array}{c}\text { Std. } \\
\text { Deviation }\end{array}$ & Variance \\
\hline $\begin{array}{l}\text { Enjoyment } \\
\text { Physical } \\
\text { Activity }\end{array}$ & 200 & 41.00 & 126.00 & 96.69 & 16.42 & 269.723 \\
\hline $\begin{array}{l}\text { Valid N } \\
\text { (listwise) }\end{array}$ & 200 & & & & & \\
\hline
\end{tabular}

Berdasarkan tabel 2 tentang deskripsi statistik kenikmatan beraktifitas fisik peserta didik sekolah menengah kejuruan dalam pendidikan jasmani, diketahui nilai rata-rata (mean) 96,69 dengan simpangan baku (std. deviation) 16.42323. Nilai minimum peserta didik adalah 41 dan nilai maksimum 126. Varian data kenikmatan beraktifitas fisik peserta didik adalah 269,723.

Deskripsi statistik data tersebut akan dilanjutkan dengan penghitungan persentase yang kemudian dikategorikan sesuai dengan PACE. Hasil penghitungan persentase dengan menggunakan rumus persentase didapatkan nilai sebagai berikut.

Tabel 4. Penghitungan Persentase Kenikmatan Beraktifitas Fisik

\begin{tabular}{|c|c|c|c|}
\hline & Nilai & Mean & $\begin{array}{c}\text { Persentase } \\
(\%)\end{array}$ \\
\hline Jumlah total & 19338 & 537,17 & \multirow{2}{*}{76,74} \\
\hline Rata-rata total & 96,69 & 5,3717 & \\
\hline
\end{tabular}

Tabel 3 tentang penghitungan persentase kenikmatan beraktifitas fisik menunjukkan hasil persentase sebesar 76,73\%. Nilai persentase tersebut dikategorikan berdasarkan skala PACE hingga dapat dikategorikan peserta didik 
menikmati aktifitas fisik selama kegiatan belajar mengajar pendidikan jasmani di sekolah menengah kejuruan.

Setelah diketahui secara keseluruhan tingkat kenikmatan beraktifitas fisik peserta didik sekolah menengah kejuruan, maka perlu dilakukan analisis persentase tiap variabel. Deskripsi statistik data per variabel adalah sebagai berikut.

Tabel 5. Deskripsi Statistik Variabel Kenikmatan Beraktifitas Fisik

\begin{tabular}{|c|c|c|c|c|c|c|c|}
\hline Variabel & $\mathrm{N}$ & Min. & $\begin{array}{c}\text { Max } \\
.\end{array}$ & Mean & $\begin{array}{c}\text { Std. } \\
\text { Deviation }\end{array}$ & Variance & $(\%)$ \\
\hline $\begin{array}{l}\text { Kenikmatan } \\
\text { beraktifitas } \\
\text { fisik }\end{array}$ & 200 & 1.00 & 7.00 & 5.42 & 1.46 & 2.15 & 79,71 \\
\hline $\begin{array}{l}\text { Ketertarikan } \\
\text { beraktifitas } \\
\text { fisik }\end{array}$ & 200 & 1.00 & 7.00 & 5.32 & 1.43 & 2.06 & 80,28 \\
\hline $\begin{array}{l}\text { Kesukaan } \\
\text { beraktifitas } \\
\text { fisik }\end{array}$ & 200 & 1.00 & 7.00 & 5.44 & 1.44 & 2.09 & 81,42 \\
\hline $\begin{array}{l}\text { Kesenangan } \\
\text { beraktifitas } \\
\text { fisik }\end{array}$ & 200 & 1.00 & 7.00 & 5.47 & 1.54 & 2.38 & 82,14 \\
\hline $\begin{array}{l}\text { Keasyikan } \\
\text { beraktifitas } \\
\text { fisik }\end{array}$ & 200 & 1.00 & 7.00 & 5.39 & 1.43 & 2.06 & 80,85 \\
\hline $\begin{array}{l}\text { Bersukacita } \\
\text { saat } \\
\text { beraktifitas } \\
\text { fisik }\end{array}$ & 200 & 1.00 & 7.00 & 5.37 & 1.40 & 1.97 & 80,14 \\
\hline $\begin{array}{l}\text { Mendapat } \\
\text { energi } \\
\text { beraktifitas } \\
\text { fisik } \\
\end{array}$ & 200 & 2.00 & 7.00 & 5.24 & 1.38 & 1.9 & 81 \\
\hline $\begin{array}{l}\text { Kebahagiaan } \\
\text { beraktifitas } \\
\text { fisik }\end{array}$ & 200 & 1.00 & 7.00 & 5.45 & 1.33 & 1.77 & 79,57 \\
\hline $\begin{array}{l}\text { Kenyamanan } \\
\text { beraktifitas } \\
\text { fisik }\end{array}$ & 200 & 1.00 & 7.00 & 5.54 & 1.23 & 1.52 & 83,42 \\
\hline $\begin{array}{l}\text { Kebaikan } \\
\text { secara fisik }\end{array}$ & 200 & 2.00 & 7.00 & 5.44 & 1.3 & 1.7 & 80 \\
\hline
\end{tabular}

Hendra Mashuri.Analisis Tingkat Kenikmatan Beraktifitas Fisik Peserta Didik Pendidikan Jasmani Sekolah Menengah 


\begin{tabular}{|c|c|c|c|c|c|c|c|}
\hline $\begin{array}{l}\text { Kekuatan } \\
\text { beraktifitas } \\
\text { fisik }\end{array}$ & 200 & 1.00 & 7.00 & 5.37 & 1.48 & 2.2 & 76,85 \\
\hline $\begin{array}{l}\text { Tidak frustasi } \\
\text { beraktifitas } \\
\text { fisik }\end{array}$ & 200 & 1.00 & 7.00 & 5.50 & 1.48 & 2.21 & 81,14 \\
\hline $\begin{array}{l}\text { Kepuasan } \\
\text { beraktifitas } \\
\text { fisik } \\
\end{array}$ & 200 & 1.00 & 7.00 & 5.42 & 1.39 & 1.94 & 83,57 \\
\hline $\begin{array}{l}\text { Kegembiraan } \\
\text { beraktifitas } \\
\text { fisik }\end{array}$ & 200 & 1.00 & 7.00 & 5.47 & 1.45 & 2.11 & 82,71 \\
\hline $\begin{array}{l}\text { Motivasi } \\
\text { beraktifitas } \\
\text { fisik }\end{array}$ & 200 & 1.00 & 7.00 & $\begin{array}{r}5.345 \\
0\end{array}$ & 1.41 & 2 & 78,71 \\
\hline $\begin{array}{l}\text { Prestasi } \\
\text { beraktifitas } \\
\text { fisik }\end{array}$ & 200 & 2.00 & 7.00 & $\begin{array}{r}5.330 \\
0\end{array}$ & 1.40 & 1.97 & 84 \\
\hline $\begin{array}{l}\text { Kesegeraan } \\
\text { beraktifitas } \\
\text { fisik }\end{array}$ & 200 & 1.00 & 7.00 & $\begin{array}{r}5.630 \\
0\end{array}$ & 1.34 & 1.8 & 85 \\
\hline $\begin{array}{l}\text { Beraktifitas } \\
\text { fisik lebih } \\
\text { baik dari } \\
\text { kegiatan lain }\end{array}$ & 200 & 1.00 & 7.00 & $\begin{array}{r}4.525 \\
0\end{array}$ & 1.84 & 3.38 & 78,57 \\
\hline
\end{tabular}

Berdasarkan tabel 4 dapat diketahui bahwa nilai rata-rata tertinggi adalah kesegaran beraktifitas fisik dengan nilai 5,63 dan masuk dalam kategori aktifitas fisik sangat memberi kesegaran kepada peserta didik. Hal ini membuktikan bahwa peserta didik merasa dengan beraktifitas fisik dalam mata pelajaran pendidikan jasmani membuat peserta didik merasa segar secara jasmani, rohani, dan sosial. Sedangkan untuk nilai terendah adalah variabel beraktifitas fisik lebih baik dari kegiatan lain dengan nilai rata-rata 4,525 dan masuk dalam kategori menikmati aktifitas fisik. Dengan kata lain, peserta didik merasa aktifitas fisik yang dilakukan lebih baik daripada kegiatan yang lainnya, seperti bincang-bincang dengan teman, beli makanan di kantin (jajan), dan nongkrong. 
Penelitian ini juga menemukan bahwa ada tiga variabel yang masuk dalam kategori sangat menikmati, yaitu variabel kenyamanan beraktifitas, aktifitas fisik yang dilakukan tidak membuat frustasi, dan aktifitas fisik memberikan kesegaran diri. Kemudian dilakukan observasi ternyata pada variabel kenyamanan, peserta didik merasa nyaman dengan gerakan (tugas gerak) yang diberikan oleh guru pendidikan jasmani. Terlihat dari peserta didik dalam melaksakan tugas gerak mereka melakukannya dengan baik dan benar sehingga mereka tidak merasa frustasi dalam tugas gerak yang diberikan oleh guru pendidikan jasmani. Pada variabel kegeran beraktifitas, peserta didik merasa dengan beraktifitas fisik dalam mata pelajaran pendidikan jasmani membuat peserta didik merasa segar secara jasmani, rohani, dan sosial. Hal ini tampak dari setelah selesai beraktifitas fisik, peserta didik lebih bersemangat untuk beraktifitas lain dan lebih antusias untuk kegiatan lain.

\section{PEMBAHASAN}

Aktifitas fisik usia remaja sangat beragam dan seharusnya aktifitas fisik yang dilakukan secara rutin untuk membakar lemak dan mengurangi resiko overweight (Zuhdy, 2015). Guru pendidikan jasmani harus mempunyai banyak metode yang menyenangkan agar peserta didik bisa termotivas untuk beraktifitas fisik. Banyak berntuk aktifitas fisik yang bisa dilakukan peserta didik, namun aktifitas fisik yang bersifat permainan lebih dipilih oleh peserta didik untuk beraktifitas fisik. Permainan merupakan kegiatan yang digunakan oleh anak (peserta didik) untuk meluapkan ekspresi, pelampiasan ketegangan, dan menirukan orang yang dikagumi atau yang dijadikan guru (Qomarrullah, 2015). Hal ini senada dengan hasil penelitian yang membuktikan bahwa secara komprehensif, peserta didik menikmati aktifitas fisik yang dilakukan selama proses belajar mengajar pendidikan jasmani di sekolah. Peserta didik merasa melalui aktifitas fisik, mereka bisa mengekspresikan dirinya dalam bentuk tugas gerak. Selain itu, peserta didik bisa melampiaskan ketegangan tugas sekolah dalam bentuk aktifitas fisik. lebuh lanjut, guru pendidikan jasmani merupakan guru yang paling banyak disukai oleh peserta didik karena guru olahraga mempunyai banyak hal yang bisa menyenangkan peserta didik melalui aktifitas 
fisik. Sehingga banyak peserta didik yang terinspirasi oleh guru pendidikan jasmani untuk beraktifitas fisik.

Kenikmatan beraktifitas peserta didik didukung oleh persepsi diri akan aktifitas fisik yang dilakukannya. Peserta didik merasa mampu dan nyaman untuk melakukan tugas gerak yang diberikan oleh guru pendidikan jasmani. Penemuan ini didukung oleh penelitian dari Timo, Sami, Anthony, \& Jarmo, (2016) yang menyatakan bahwa persepsi diri tentang kemampuan individu yang timbul dari interaksi dengan lingkungan yang berkaitan dengan aktifitas fisik selama pubertas memiliki efek yang berpengaruh pada perilaku fisik selanjutnya. Timo dkk menemukan bahwa peserta didik usia remaja (pubertas) untuk beraktifitas fisik harus dipengaruhi oleh persepsi diri akan kemampuan dirinya sendiri dalam aktifitas fisik. Peserta didik sekolah menengah kejuruan memiliki persepsi diri akan kemampuan dirinya terhadap aktifitas fisik yang diberikan oleh guru pendidikan jasmani, sehingga peserta didik merasa nhaman akan aktifitas tersebut. Gerakan yang nyaman dan tidak membuat peserta didik susah dalam pelaksanaan tugas gerak akan membuat peserta didik tidak frustasi sama sekali. Hal ini dapat ditunjukkan dalam temuan penelitian ini.

Aktifitas fisik selama proses belajar mengajar pendidikan jasmani juga bisa membuat tubuh siswa lebih segar. Kesegaran tubuh biasa disebut dengan kesegaran jasmani atau kebugaran jasmani. Penelitian ini menunjukkan bahwa peserta didik merasa segar setelah melakukan aktifitas fisik dalam proses belajar mengajar pendidikan jasmani. Peserta didik merasa setelah melakukan aktifitas fisik tubuhnya kembali segar dan siap untuk melakukan aktifitas lain, yaitu pelajaran lain. Seperti pernyataan Muhajir (2005 dalam Novitasari \& Suroto, 2016) bahwa kesegaran jasmani merupakan kemampuan tubuh untuk melakukan aktifitas fisik secara terus menerus dalam waktu yang lama tanpa mengalami kelelahan. Sehingga peserta didik setelah beraktifitas fisik tidak mengalami kelelahan namun akan memberikan energi baru untuk melakukan kegiatan lain.

\section{SIMPULAN}

Kenikmatan beraktifitas fisik peserta didik sekolah menengah kejuruan dalam pendidikan jasmani menunjukkan bahwa peserta didik menikmati aktifitas 
fisik yang dilakukan selama kegiatan belajar mengajar pendidikan jasmani. Kenikmatan beraktifitas fisik yang menonjol dari peserta didik yaitu perasaan bahwa aktifitas fisik (tugas gerak) yang dilakukan membuat peserta didik nyaman, tanpa ada yang merasa kesusahan dan tidak membuat frustasi peserta didik. Selain itu ternyata peserta didik merasa aktifitas yang dilakukan memberikan kesegaran dan memberikan semangat untuk beraktifitas atau melakukan kegiatan lain setelah mata pelajaran pendidikan jasmani.

\section{DAFTAR RUJUKAN}

Abduljabar, B. (2011). Pengertian pendidikan jasmani. Ilmu Pendidikan.

Brustad, R. J. (2016). Affective Outcomes in Competitive Youth Sport: The Influence of Intrapersonal and Socialization Factors. Journal of Sport and Exercise Psychology. https://doi.org/10.1123/jsep.10.3.307

Carroll, B., \& Loumidis, J. (2001). Children's Perceived Competence and Enjoyment in Physical Education and Physical Activity Outside School. European Physical Education Review. https://doi.org/10.1177/1356336X010071005

Direktorat Jendral Pendidikan Dasar dan Menengah, K. P. dan K. (2019). Data Pokok Pendidikan Dasar dan Menengah. Retrieved from http://dapo.dikdasmen.kemdikbud.go.id/

Firdausi, A. R., \& Barnawi. (2012). Profil Guru SMK Profesional. Yogyakarta: Ar-Ruz Media.

Gill, D. L., Gross, J. B., \& Huddleston, S. (1983). Participation Motivation in Youth Sports. International Journal of Sports Psychology.

Gunawan, E. E. (2019). Motivasi Bermain Bola Basket Siswa Sma Negeri 12 Makassar. Jp.Jok (Jurnal Pendidikan Jasmani, Olahraga Dan Kesehatan), 2(2), 14-23. https://doi.org/10.33503/jpjok.v2i2.447

Hanief, Y. N., Subekti, T. B. A., \& Mashuri, H. (2018). Meningkatkan Hasil Belajar Passing Bawah Bolavoli melalui Permainan 3 on 3 pada Siswa Sekolah Dasar. Jurnal Pendidikan Jasmani Dan Olahraga. https://doi.org/10.17509/jpjo.v3i2.12414

Kendzierski, D., \& DeCarlo, K. J. (2016). Physical Activity Enjoyment Scale: 
Two Validation Studies. Journal of Sport and Exercise Psychology. https://doi.org/10.1123/jsep.13.1.50

Mashuri, H. (2017). Persepsi Siswa Terhadap Pembelajaran Guru Pendidikan Jasmani Di Sma Muhammadiyah Kediri. Jurnal Pembelajaran Olahraga, 3, 1-10. Retrieved from http://ojs.unpkediri.ac.id/index.php/pjk/index

Novitasari, D. A., \& Suroto, S. (2016). Tingkat Konsumsi Energi, Aktivitas Fisik Dan Kesegaran Jasmani Pada Posisi (Tosser Dan Smasher) Atlet Bola Voli. Jurnal Kesehatan Masyarakat (e-Journal).

Presiden Republik Indonesia. (1990). Peraturan Pemerintah Presiden Republik Indonesia Nomor 29 Tahun 1990 Tentang Pendidikan Menengah. 1990, 5679.

Qomarullah, R., Furqon, M. H., \& Kristiyanto, A. (2015). Model Aktivitas Belajar Gerak Berbasis Permainan Sebagai Materi Ajar Pendidikan Jasmani. Journal of Physical Education Health and Sport.

Showab, A., \& Djawa, B. (2019). Pengaruh Modifikasi Permainan Bola Voli Terhadap Kegembiraan Belajar Siswa. Bernard Djawa. Jurnal Pendidikan Olahraga Dan Kesehatan2, 07(03), 307-312.

Timo, J., Sami, Y. P., Anthony, W., \& Jarmo, L. (2016). Perceived physical competence towards physical activity, and motivation and enjoyment in physical education as longitudinal predictors of adolescents' self-reported physical activity. Journal of Science and Medicine in Sport. https://doi.org/10.1016/j.jsams.2015.11.003

Utama, A. M. B. (2011). Pembentukan Karakter Anak Melalui Aktivitas Bermain Dalam Pendidikan Jasmani. Pendidikan Jasmani Indonesia.

Wibowo, P. A. (2018). Peningkatan Keaktifan Siswa Dalam Permainan Futsal Melalui Metode Tgt Pada Siswa Kelas X Di Sma Selamat Pagi Indonesia Kota Batu. Jp.Jok (Jurnal Pendidikan Jasmani, Olahraga Dan Kesehatan), 1(2), 14-23. https://doi.org/10.33503/jpjok.v1i2.164

Winarno, M. E. (2006). Dimensi Pembelajaran Pendidikan Jasmani Dan Olahraga. In Laboratorium Jurusan Ilmu Keolahragaan Fakultas Ilmu Pendidikan Universitas Negeri Malang.

Zuhdy, N. (2015). Hubungan pola aktivitas fisik dan pola makan dengan status 
gizi pada pelajar putri sma kelas 1 di denpasar utara. Tesis. https://doi.org/10.1002/nau.20769 